\title{
Strategic Orientations and SME Performance: Moderating Effect of Absorptive Capacity of the Firm
}

\author{
Herath H. M. A ${ }^{1} \&$ Rosli Mahmood ${ }^{2}$ \\ ${ }^{1}$ Department of Business Management, Wayamba University of Sri Lanka, Kuliyapitiya, Sri Lanka \\ ${ }^{2}$ College of Business, Universiti Utara Malaysia, Sintok, Kedah, Malaysia \\ Correspondence: Rosli Mahmood, College of Business, Universiti Utara Malaysia, 06010 UUM Sintok, Kedah, \\ Malaysia. Tel: 604-928-7495. E-mail: rosli@uum.edu.my
}

Received: April 3, 2014 Accepted: May 22, 2014 Online Published: June 25, 2014

doi:10.5539/ass.v10n13p95

URL: http://dx.doi.org/10.5539/ass.v10n13p95

\begin{abstract}
This paper examines the effect of recent configuration of strategic orientation on SME performance and the moderating effect of absorptive capacity of the firm. Data from 350 owner-managers of small and medium scale hotel and restaurants in Sri Lanka were used with structural equation modelling. The structural model investigates the direct effects of market, entrepreneurial, and learning orientations on firm performance and moderating effect of absorptive capacity. Results indicate that SMEs with high level of absorptive capacity would achieve higher performance by maintaining higher level of strategic orientation.
\end{abstract}

Keywords: SME performance, strategic orientations, absorptive capacity

\section{Introduction}

The role of the small and medium scale enterprises (SMEs) has been critical and the sector is considered as the "backbone" of many economies (Wymenga, Spanikowa, Baker, Konings, \& Canton, 2012). An impressive empirical support has also been received for its importance for the developing countries in achieving their socio-economic development targets (Subhan, Mehmood, \& Sattar, 2013; Asian Productivity Organization, 2011). However, the SME sector in the developing nations faces many constraints such as technological backwardness, low level of human resource skills, weak management systems and entrepreneurial capabilities, unavailability of appropriate and timely information, insufficient use of information technology and poor product quality. Consequently the economic contribution of SMEs in these countries is currently far behind compared to developed countries (Altenburg \& Eckhardt, 2006; Emine, 2012; Panday, 2012; Asian Productivity Organization, 2011). Accordingly, low level of performance in SMEs sector is one of the key issues in most of the developing countries though they have been expected to play a critical role in their economies, and the current globalized competitive rivalry has multiplied the importance of the issue.

The performance of SME has been the focus of many prior researchers making it one of the most widely used construct as a dependent variable (Rogers \& Wright, 1998; March \& Sutton, 1997; Carton \& Hofer, 2010). Many of the previous SME performance models have incorporated both internal and external variables to explain the complex relationships with performance (eg. Islam, Khan, \& Obaidullah, 2011; Beneki, 2011; Enriquez, Adame, \& Camacho, 2011; Leitner \& Idenberg, 2010; Inmyxai \& Takahashi, 2009; Mancinelli \& Mazzanti, 2009). Findings are however, inconsistent and any of the combination of variables has not explained the phenomenon to a satisfactory extent.

Studies have suggested that strategic orientation is critical for the long-term survival of the firm with higher level of performance. Different strategic orientations such as market orientation, entrepreneurial orientation, learning orientation, technology orientation, product orientation, resource orientation and customer orientation have been used to explain the phenomenon (Ledwith \& Dwyer, 2009; Li, Zhao, Tan, \& Liu, 2008; Gao, Zhou, \& Yim, 2007; Kropp, Lindsay, \& Shoham, 2008). However, most of the related research have attempted to investigate the effect of single orientation and combined with other contextual factors (Hakala, 2011; Kropp, Lindsay, \& Shoham, 2006). Recent studies further argued that the strategic orientation concept used in previous research is fragmented and representing only a disconnected and partial view. Consequently, Hakala (2010) configured the concept of strategic orientation by integrating four different perspectives of strategic elements; entrepreneurial 
orientation, market orientation, technology orientation and learning orientation and viewed them as templates for the ways of conducting business activity to maintain and improve the organizational performance. Prior to this configuration of the concept, the collective role of entrepreneurial orientation, market orientation and learning orientation in performance models has been investigated in twelve studies among which two were conducted to investigate the corporate entrepreneurship in state-owned companies (Liu, Luo, \& Shi, 2002, 2003), and another two studies were in small sample of non-for-profit organizations (Barrett, Balloun, \& Weinstein, 2005a; 2005b). Hult, Ketchen, and Slater (2005) and Zehir and Eren (2007) conducted their studies in the samples of large-scale firms, other two studies investigated the effect of the three orientations on new venture performance and internationalization of international companies (Roukenon \& Saarenketo, 2009; Kropp et al., 2008), while Rhee, Park, and Lee (2010) investigated the innovation performance of technology intensive firms. Nonetheless, no study has yet investigated the effect of the three orientations on the firm level business performance of small and medium scale enterprise, though some studies had proposed the conceptual models that have not been empirically tested (Herath \& Mahmood, 2012, 2013a, 2013b).

Firm performance and behaviour is also influenced by the way of absorbing and accumulating knowledge, and absorptive capacity of the firm is now considered as critical not only for the success of larger firms but also SMEs (Zonooz, Farzam, Satarifar, \& Bakhdhi, 2011; Klette \& Johensen, 1998). Due to the importance of the construct, many scholars have suggested for further investigation to clarify its role (Sun \& Anderson, 2010; Zhou \& Li, 2010), while others have emphasized the need of clarifying its role in different contexts such as developing countries (Astrid, Cristina, \& Ruzana, 2008), or service industry (Harvey, Skelcher, Jas, \& Walshe, 2010). Although existing literature have revealed that many of the previous performance models used the construct as a predictor variable (Yeoh, 2009; Zahara \& George, 2002; Lane, Salk, \& Lyles, 2001), only four studies have investigated the moderating role and two studies on the mediating roles of the construct (Zhang, 2009; Hou, 2008). The moderating role of absorptive capacity in the relationship between knowledge acquisition and performance was the focus of two studies by Lin-Van, De-Van, and Yun- Horng, (2010), and Wang and Han (2011). Another study considered the moderating role of absorptive capacity in the relationship between innovative performance and market orientation (Yang-Chao, Shun-Lin, Lin-Cheng, \& Chia-Liao, 2011) while another study investigated the relationship between organizational resources and performance (Kim, Zhan, \& Erramilli, 2011). The role of absorptive capacity in the SME performance models, however, is yet to be clarified. In this paper, we examine the effect of market, entrepreneurial and learning orientations on SME performance and the moderating effect of absorptive capacity of the firm.

\section{Literature Review}

\subsection{Firm Performance}

Firm performance generally refers to the organizational success, and success is considered as achieving organizational goals (Foley \& Green, 1989). According to Kaplan and Norton (1996), firm performance is a multidimensional concept and all aspects of performance are relevant to the success of the organization. Firm performance has been widely used by many researchers mainly in two disciplines. It is at the heart of strategic management (Venkatraman \& Ramanujam, 1986) and the construct was measured mainly in financial aspects (Rogers \& Wright, 1998). Consequently, wide range of measures of firm performance such as profitability (eg. net profit, ROI) growth (eg. market share, turnover) and survival have been used by researchers making little consensus on the measurement (Carton \& Hofer, 2010; Brush \& VanderWerf, 1992).

\subsection{Strategic Orientation and Firm Performance}

Venkatraman (1989) first used the term strategic orientation and conceptualized the concept with six dimensions namely; aggressiveness, analysis, defensiveness, futurity, proactiveness and riskiness. According to Gatignon and Xuereb (1997), strategic orientation is the principle that directs the organizational activities and behaviours essential for the performance of the firm. It represents different mechanisms of organizational adaptation. Hakala (2010) described it as templates for the ways of conducting business activity to maintain and improve the organizational performance. Scholars have considered that both market orientation and entrepreneurial orientation have positive influence on firm performance (Slater \& Narver, 2000; Lin, Peng, \& Kao, 2008; Reijonena \& Komppulab, 2010; Fauzul, Takenouchi, \& Yukiko, 2010; Chandrakumara, De Zoyza, \& Manawaduge, 2011; Wang, 2008). Although market orientation has been found to be positively related to sustainable competitive advantage (Aziz \& Yassin, 2010) and innovation performance (Mavondo, Chimhanzi, \& Stewart, 2005), a number of studies have also proven that market orientation is a poor predictor SME performance and even detrimental when the demand uncertainty is at a higher level (Gao, Zhou, \& Yim, 2007; Ledwith \& Dwyer, 2009). 
Firm performance has been positively influenced by market orientation combined with innovation orientation (Appaiah \& Singh, 1998), resource orientations (Paladino, 2009), technology orientation (Jeong, Pae, \& Zhou, 2006), product orientation (Shaw, 2000; Fritz, 1996), entrepreneurial orientation (Bhuian, Mengue, \& Bell, 2005; Frishammar \& Horte, 2007; Schindehutte, Morris, \& Kocak, 2008; Baker \& Sinkula, 2009; Tajeddini, 2010; Hoq \& Chauhan, 2011) and learning orientation(Lee \& Tsai, 2005; Atuahene-Gima, Slater, \& Olson, 2005; Baker \& Sinkula, 2002; Keskim, 2006). Studies by Liu, Luo, and Shi (2002) and Liu, Luo, and Shi (2003) found positive effect of entrepreneurial orientation, market orientation and learning orientation on corporate entrepreneurship, while Barrett, Balloun, and Weinstein (2005a, 2005b) found that entrepreneurial orientation, market orientation and learning orientation correlates with performance of non-profit organizations. Hult, Hurley, and Knight (2004) and Zehir and Eren (2007) further found that entrepreneurial orientation, market orientation and learning orientation are all positively related to performance of large-scale organizations while Ruokonen and Saarenketo (2009) and Kropp et al. (2008) have tested the effects of the three orientations on new venture performance and internationalization. Meanwhile Rhee et al. (2010)'s study found simultaneous effect of entrepreneurial orientation, market orientation, learning orientation on innovation performance, Li (2005) concurred that entrepreneurial orientation, market orientation and technology orientation have positive effect on networking and performance, and Salavou (2005) found that learning orientation, market orientation and technology orientation have a combined effect on new product performance.

\subsection{Absorptive Capacity and Firm Performance}

Cohen and Levinthal (1990) defined absorptive capacity as "the ability of a firm to recognize new external information, assimilate it and apply it to commercial ends", and claimed that it creates a firm's competitive advantage. Absorptive capacity has been investigated in a number of performance models in prior research, and many of these studies have proven positive relationship with firm performance (Yeoh, 2009; Lichtenthaler, 2009; Bergh \& Lim, 2008; Murray \& Peyrefitte, 2007; Flatten, Greve, \& Brettel, 2011; Ng, 2011; Parida, 2009). Deeds (2001) found absorptive capacity to positively influence new wealth creation, while Huang and Rice (2009) and Jolly and Therin (2007) found that firms easily assimilate knowledge to develop innovations. Muscio (2007) proved that absorptive capacity improves the collaboration with other organizations, and Hayton and Zahra (2005) found that it increases the ability to acquire additional resources. Liao, Welsch, and Stoica (2003) also found that knowledge acquisition is positively related to organizational responsiveness of growth-oriented SMEs, while Brettel, Greve, and Flatten (2011) suggested curvilinear relationship between absorptive capacity and performance of the firm. Other studies have tested absorptive capacity as a moderator and found significant effects (Lin-Van, De-Van, \& Yun- Horng, 2010; Wang \& Han, 2011; Yang-Chao, Shun-Lin, Lin-Cheng \& Chia-Liao, 2011; Kim, Zhan, \& Erramilli, 2011), and Hou, (2008) and Zhang (2009) have proved a significant mediating role of absorptive capacity in the performance models.

\section{Research Model and Hypotheses}

Hakala's (2010) configuration of strategic orientation comprises of constellation of entrepreneurial, market, learning and technology orientations. It supposes that it is a combination of the value position of the firm in the markets, its resources, and behavioural patterns relating to how the organization transforms its resources into performance. This constellation blankets wide range of behaviours and resources such as proactiveness, risk adjusting continuously to the dynamic environment, adapting new internal and external conditions, and taking behaviour, Innovativeness, shared vision, commitment to continuous learning, competitiveness, open-mindedness, and customer needs. These resources and behaviours lead organizations to perform well by responding to customer needs and competitors' challenges (Sinkula, Baker, \& Noordewier, 1997; Lumpkin \& Dess, 1996; Narver \& Slater, 1990; Covin \& Selvin, 1989). Based on the assumption that firms which maintain this new configuration of strategic orientation have the possibility of achieving higher performance level, the following hypotheses were formulated.

$\mathrm{H}_{1:}$ There is a positive relationship between entrepreneurial orientation and firm performance

$\mathrm{H}_{2:}$ There is a positive relationship between market orientation and firm performance

$\mathrm{H}_{3}$ : There is a positive relationship between learning orientation and firm performance

Strategic orientations are interpreted as organizational resources and behaviours (Barney, 1991; Hakala, 2010; Hoq \& Chauhan, 2011). The resource based and knowledge-based views of the firm have stressed that resources alone cannot achieve the competitive advantage and the firms with stronger dynamic capabilities are capable of exploiting available bulk of organizational resources (Grant, 1996; Newbert, Gopalakishnan, \& Kirchoff, 2008). Newbert et al. (2008) reported that the higher level of firm's internal capabilities of leveraging resources leads the firms to outperform their rivals with low level of such capacities. Some scholars have also posited that 
absorptive capacity plays a pivotal role among other dynamic capabilities in exploiting the prevailing bulk of organizational resources since knowledge acquisition and absorption are key features of exploiting opportunities (Frishammar \& Andersson, 2007; Hou, 2008; Sun \& Anderson, 2010). This theoretical premise provides a base for reasonable assumption that the existence of absorptive capacity that can exploit organizational resources would make the relationship between strategic orientation and firm performance stronger and directional. Accordingly this study formulated the following three hypotheses.

$\mathrm{H}_{4}$ : Absorptive capacity moderates the relationship between entrepreneurial orientation and firm performance

$\mathrm{H}_{5}$ : Absorptive capacity moderates the relationship between market orientation and firm performance

$\mathrm{H}_{6:}$ Absorptive capacity moderates the relationship between learning orientation and firm performance

The graphical representation of the research model is shown in Figure 1 below.

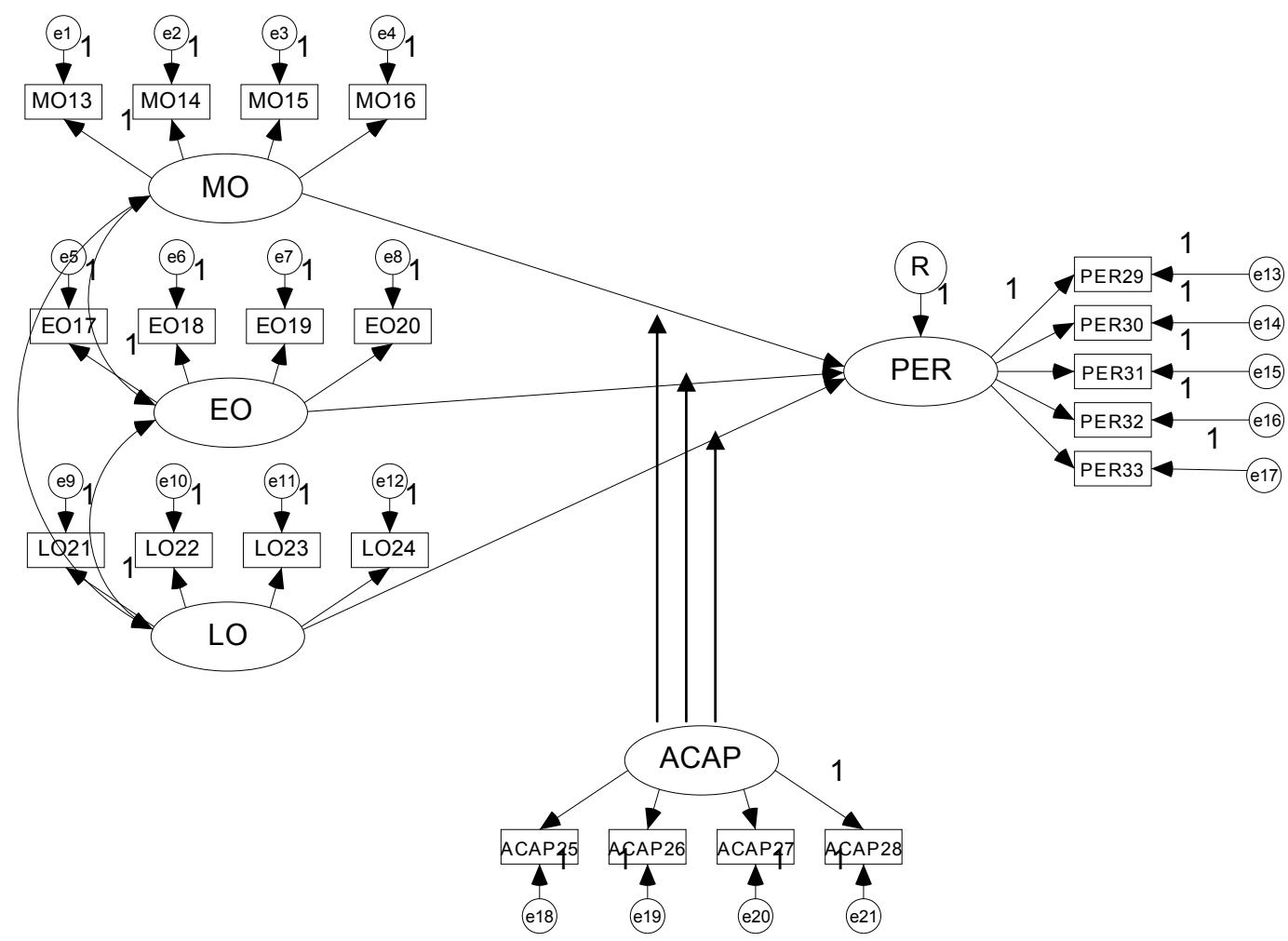

$\mathrm{MO}=$ market orientation, $\mathrm{EO}=$ entrepreneurial orientation, $\mathrm{LO}=$ learning orientation, $\mathrm{ACAP}=$ absorptive capacity, $\mathrm{PER}=$ performance

Figure 1. Research model

\section{Methodology}

\subsection{Research Design}

A field survey was conducted in randomly selected sample of small and medium scale hotel and restaurants in Sri Lanka. A questionnaire was administered among 500 respondents who were dispersed all over the island. The data collection process went through eight weeks and 380 completed questionnaires were received. Thirty responses were eliminated after scrutinizing for incompleteness and treatment of univariate and multivariate outliers. Market orientation was measured with the questionnaire developed by Naver and Slater (1990). The variable included three dimensions namely; customer orientation, competitor orientation and inter-functional coordination. Entrepreneurial orientation, which comprised of innovativeness, risk taking, and proactiveness, was measured by 12-item scale developed by Covin and Selvin (1989). Shared vision, commitment to learning and open mindedness, are the dimensions of learning orientation, which was measured with the scale developed by Sinkula et al. (1997). Absorptive capacity was measured by using the questionnaire developed by Flatten et al. 
(2011). Five-point Likert scale ranging from 1 (strongly disagree) to 5 (strongly agree) was used to measure responses to each item.

\subsection{Data Analysis}

Data were analysed using structural equation modelling. Three direct structural paths were estimated with testing the direct effect model and moderating effects were estimated with multi group analysis. The respondents on the moderating variable absorptive capacity were divided into two groups. Respondents with mean for absorptive capacity greater than 3.5 were considered as high absorptive capacity group while mean for absorptive capacity with less than 3.5 were considered as low absorptive capacity group. This process created two groups with 155 respondents in high absorptive capacity group and 195 for low absorptive capacity group. The measurement invariance across two groups was evaluated by testing the measurement model as configural invariance model separately in two groups. If the difference of overall model fit across two groups is not significant the measurement invariance was established and groups are therefore suitable for comparison (Schoot, Lugtig, \& Hox, 2012).

Having assured the measurement invariance, the baseline model was estimated across low and high groups with all free path estimates. Then the constrained model with the paths from market orientation, entrepreneurial orientation and learning orientation to performance constrained to equal values were assessed across two groups. Finaly $\chi^{2}$ difference between baseline, non-constrained model and constrained model were conducted. If the $\chi^{2}$ difference is statistically significant, there exists a moderating effect. $\chi^{2}$ difference idicates only the existence of a moderating effect. To determine direction and the magnitude of moderating effect, regression weights and squared multiple correlations were examined. If the regression weights of the moderating paths of higher absorptive capacity group are higher than that of low absorptive capacity group, higher level of moderating effect exists. Similarly higher squared multiple correlation for higher absorptive capacity group denotes high level of moderating effects.

\section{Results}

The structural model with direct relationships proved overall model fit with $\chi^{2}=239.063$ and $d f=113$. All overall model fit indices recorded a good model fit $(\mathrm{CMIN} / \mathrm{df}=2.11, \mathrm{CFI}=.954$, and RMSEA=.047). Regression weights for direct paths are shown in the Table 1. Regression weights for direct paths in the Table 1 show that all values are positive and significant at 001 level.

Table1. Estimated regression weights for direct paths

\begin{tabular}{cc}
\hline Direct path & Standardised regression weight \\
\hline MO $>$ PER & .361 \\
EO $>$ PER & .572 \\
LO $>$ PER & .425 \\
\hline
\end{tabular}

The baseline model well fit across both low absorptive capacity group and high absorptive capacity group with $\chi^{2}=406.755$ and $d f=226$. All overall model fit indices recorded a good model fit $(\mathrm{CMIN} / \mathrm{df}=1.800, \mathrm{CFI}=.932$, and RMSEA =.048). The constrained models with structural parameters on market orientation, entrepreneurial orientation, learning orientation and performance constrained to fixed values has also reported a good model fit with $\chi^{2}=820.363$, and $d f=232$. Overall fit indices have reported a good model fit (CMIN/df=1.607, CFI $=.904$, and RMSEA =.042). The results of the comparison of $\chi^{2}$ values and other model fit indices are given in the Table 2. Information presented in Table 2 indicates that the Chi-Square value has increased for the constrained model by $\Delta \chi^{2}=213.608$ and $\Delta d f=6$ and the difference for the two models was significant at .001 . This result provides clear evidence for inequality of parameters on the structural paths between market orientation, entrepreneurial orientation, learning orientation and performance across low and high absorptive capacity groups.

Standardized $\beta$ values for the structural paths of the baseline model across two groups are given in Table 3 . The $\beta$ values in the Table 3 indicate that the effect of high absorptive capacity group on the relationship between market orientation, entrepreneurial orientation, learning orientation and performance is higher while there is a comparatively lower effect from low absorptive capacity group. For example, the effect of high absorptive capacity group on the relationship between market orientation and performance indicates a value of $.447 \mathrm{p}<.001$. But the same value for low absorptive capacity group is .159, $\mathrm{p}<.001$ which shows a significant deterioration compared to high absorptive capacity group. This is true for the other two estimated paths. 
Table 2. Results of multi group analysis

\begin{tabular}{cccccc}
\hline Model & $\mathrm{X}^{2}$ & $d f$ & $\chi / d f$ & CFI & RMSEA \\
\hline Configural model with all parameters free across groups & 406.755 & 226 & 1.800 & .932 & .048 \\
Model with constrained parameters across two groups & 620.363 & 232 & 2.607 & .904 & .052 \\
Difference & 213.608 & 06 & & & \\
\hline
\end{tabular}

Table 3. Estimated parameters for high and low ACAP groups

\begin{tabular}{ccc}
\hline Structural Path & Low ACAP group $(\beta)$ & High ACAP group $(\beta)$ \\
\hline MO $>$ PER & $.159^{*}$ & $.447^{*}$ \\
EO $>$ PER & $.382^{*}$ & $.435^{*}$ \\
LO $>$ PER & $.143^{*}$ & $.147^{*}$ \\
\hline
\end{tabular}

*significant at .05

The squared multiple correlations for estimated parameters were also used to determine the explained variance of the dependent variable by the independent variables (Byrne, 2010). Table 4 displays the estimated squared multiple correlations values for variables. As per the Table 4, variance of performance explained by market orientation, entrepreneurial orientation and learning orientation in low absorptive capacity group was considerably lower than that of high absorptive capacity group. For example, the variance of performance explained by market orientation for low absorptive capacity group is .47 while it is .88 for higher absorptive capacity group. The squared multiple correlations for entrepreneurial orientation and learning orientation for low absorptive capacity group is .465 and .430 respectively. The same values for high absorptive capacity group is .770 and .663 respectively. It clearly shows that the variance explained in low absorptive capacity group is less than that of high absorptive capacity group.

Table 4. Squared multiple correlations

\begin{tabular}{ccc}
\hline Structural Path & Low ACAP group (SMC) & High ACAP group (SMC) \\
\hline MO $>$ PER & .470 & .880 \\
EO $>$ PER & .465 & .770 \\
LO $>$ PER & .430 & .663 \\
\hline
\end{tabular}

A summary of the results of the chi square difference test between baseline model and constrained model, parameters estimation and squared multiple correlations for low and high absorptive capacity groups is given in Table 5.

Table 5. Summary results of testing moderating effects

\begin{tabular}{cccccc}
\hline Moderating & $\chi^{2}$ & \multicolumn{2}{c}{$\beta$ for ACAP groups } & \multicolumn{2}{c}{ SMC for ACAP groups } \\
\cline { 3 - 6 } Path & difference & Low & High & Low & High \\
MO $>$ PER & significant & .159 & .447 & .470 & .880 \\
EO $>$ PER & significant & .382 & .435 & .465 & .770 \\
LO $>$ PER & significant & .143 & .147 & .430 & .663 \\
\hline
\end{tabular}




\section{Testing Hypotheses}

As shown in Table 1, the regression parameters for three direct paths are in the expected direction $(\beta>0)$ and statistically significant $(\mathrm{p}<.001) . \beta$ value estimated for the direct path from market orientation to performance reports .361 and therefore the hypothesis $\mathrm{H}_{1}$ is accepted. Hypothesis $\mathrm{H}_{2}$ that represents the direct path from entrepreneurial orientation and firm performance is accepted with estimated $\beta$ value of .572 . The hypothesized path from learning orientation to firm performance reports .425 and $\mathrm{H}_{3}$ is also accepted. For hypothesis $4\left(\mathrm{H}_{4}\right)$, the absorptive capacity moderates the relationship between market orientation and firm performance. Results of chi square difference test showed the existence of moderating effect of absorptive capacity on the relationship between market orientation and performance. Regression estimates for the high absorptive capacity group and low absorptive capacity group were .447 and .159 respectively. Squared multiple correlations for low absorptive capacity group was .470 and for high absorptive capacity group .880 . This result proved that effect of absorptive capacity on the relationship between market orientation and performance was greater in higher absorptive capacity SMEs. Therefore $\mathrm{H}_{4}$ can be accepted. The absorptive capacity moderates the relationship between entrepreneurial orientation and firm performance in hypothesis 5. Results of chi square difference test showed the existence of moderating effect of absorptive capacity on the relationship between entrepreneurial orientation and performance. Regression weight for low absorptive capacity group .382 and for high absorptive capacity group is .435 . It shows that the effect of entrepreneurial orientation on performance is low in low absorptive capacity group. It is further verified by squared multiple correlations values for two groups. Squared multiple correlation for low absorptive capacity group and high absorptive capacity group is .770 and .465 respectively. These results proved that the effect of entrepreneurial orientation on performance is higher in high absorptive capacity firms than low absorptive capacity firms. These results supported the hypothesis and $\mathrm{H}_{5}$ is accepted.

Finally it was hypothesized that absorptive capacity moderates the relationship between learning orientation and firm performance. Results of the chi square difference test between baseline model and constrained model has supported the existence of moderating effect. $\beta$ coefficient for the path from learning orientation to firm performance in low absorptive capacity group .143 and the same value for the same relationship in higher absorptive capacity group was .147. It shows that the value is greater in higher absorptive capacity group. Squared multiple correlations values for the relationship between learning orientation and performance in low absorptive capacity group .430 and the same value for low absorptive capacity group is .663 . These results indicated that the relationship between learning orientation and performance is higher in high absorptive capacity group than in low absorptive capacity group. Therefore, the hypothesis $\mathrm{H}_{6}$ is supported by the findings.

\section{Conclusion}

The current study argued that the configuration of market orientation, learning orientation and entrepreneurial orientation as strategic orientation would be a good predictor variable to the firm performance. This argument was supported by the findings and that being market, entrepreneurial and learning oriented were more important in achieving firm performance. Absorptive capacity was included as a moderating variable to the relationship. This was very successful and supported the premise behind the theory of dynamic capabilities that indicates the importance of such capabilities for the SMEs as emphasized in recent studies. This study found clear statistical evidence for moderating impact of absorptive capacity on the relationship between strategic orientation and firm performance. This result implied that strategic orientation with higher absorptive capacity would improve the performance of SMEs. Further attention of researchers of the theory of dynamic capabilities that emphasize the implication of absorptive capacity in exploiting strategic orientation for the success of SMEs was demanded by these findings.

\section{References}

Altenburg, T., \& Eckhardt, U. (2006). Productivity Enhancement and Equitable Development: Challenges for SME Development. Vienna: United Nations Industrial Development Organization (UNIDO).

Appiah-Adu, K., \& Singh, S. (1998). Customer orientation and performance: A study of SMEs. Management Decision, 36(6), 385-394. http://dx.doi.org/10.1108/00251749810223592

Asian Productivity Organization. (2011). APO Productivity Data Book. Japan: Keio University Press Incorporation.

Astrid, S., Cristina, C., \& Ruzana, A. (2008). Building absorptive capacity in less developed countries: The Case of Tanzania. Retrieved February 18, 2012, from http://www.circle.lu.se/publications

Atuahene-Gima, K., Slater, S., \& Olson, E. (2005). The contingent value of responsive and proactive market orientations for new product programme performance. Journal of Product Innovation Management, 22(6), 
464-482. http://dx.doi.org/10.1111/j.1540-5885.2005.00144.x

Aziz, N. A., \& Yasin, N. M. (2010). How will market orientation and external environment influence the performance among SMEs in agro-food sector in Malaysia. International Business Research, 3(3), 154-164.

Baker, W. E., \& Sinkula, J. M. (2002). Learning orientation, market orientation and innovation: Delving into the organization's black box. Journal of Market Focused Management, 5(1), 5-23. http://dx.doi.org/10.1023/A:1012543911149

Baker, W. E., \& Sinkula, J. M. (2009). The complimentary effects of market orientation and entrepreneurial orientation on profitability in small businesses. Journal of Small Business Management, 47(4), 443-464. http://dx.doi.org/10.1111/j.1540-627X.2009.00278.x

Barney, J. (1991). Firm resources and sustained competitive advantage. Journal of Management, 17(1), 99-120. http://dx.doi.org/10.1177/014920639101700108

Barret, H., Balloun, J., \& Weinstein, A. (2005a). Success factors for organizational performance: Comparing business services, health care and education. S.A.M. Advanced Management Journal, 70(4), 16-28.

Barrett, A., Balloun, J., \& Weinstein, A. (2005b). The impact of creativity on performance in non-profits. International Journal of Non-profit and Voluntary Sector Marketing, 10(4), 213-223. http://dx.doi.org/10.1002/nvsm.25

Beneki, C., Papastathopoulos, A. (2011). A log linear analysis of factors affecting performance of European manufacturing SMEs. International Journal of Management and Marketing Research, 4 (3), 75-93.

Bergh, D., \& Lim, E. (2008). Learning how to restructure absorptive capacity and improvisational views restructuring actions and performance. Strategic Management Journal, 29, 593-616. http://dx.doi.org/10.1002/smj.676

Bhuian, S. N., Menguc, B., \& Bell, S. J. (2005). Just entrepreneurial enough: The moderating effect of entrepreneurship on the relationship between market orientation and performance. Journal of Business Research, 58(1), 9-17. http://dx.doi.org/10.1016/S0148-2963(03)00074-2

Brettel, M., Greve, G. I., \& Flatten, T. C. (2011). Giving up linearity: Absorptive capacity and performance. Journal of Managerial Issues, 2(summer), 164-189.

Brush, C. G., \& Vanderwerf, P. A. (1992). A comparison of methods and sources for obtaining estimates of new venture performance. Journal of Business Venturing, 7(March), 157-170. http://dx.doi.org/10.1016/ 0883-9026(92)90010-O

Carton, R. B., \& Hofer, C. W. (2010). Organizational financial performance: Identifying and testing multiple dimensions. Academy of Entrepreneurship Journal, 6(1), 1-22.

Chandrakumara, A., De Zoysa, A., \& Manawaduge, A. (2011). Effect of the entrepreneurial and managerial orientations of owner-managers on company performance: An empirical test in Sri Lanka. International Journal of Management, 28(1), 139-151.

Cohen, W. M., \& Levinthal, D. A. (1990). Absorptive Capacity: A new perspective of learning innovation. Administrative Science Quarterly, 35(1), 128-152. http://dx.doi.org/10.2307/2393553

Covin, J. G., \& Selvin, D. P. (1989). Strategic management of small firms in hostile and benign environment. Strategic Management Journal, 10, 75-87. http://dx.doi.org/10.1002/smj.4250100107

Deeds, D. (2001). The role of R\&D intensity, technical development and absorptive capacity in creating entrepreneurial wealth in high technology start-ups. Journal of Engineering and Technology Management, 18, 29-48. http://dx.doi.org/10.1016/S0923-4748(00)00032-1

Emine, D. (2012). Financial challenges that impede increasing the productivity of SMEs in Arab region. Journal of Contemporary Management, 1, 17-32.

Enriquez, L. A., Adame, M., \& Camacho, R. R. (2011). Small business competitiveness model for strategic sectors. Advances in Competitiveness Research, 19(3/4), 58-73.

Fauzul, M. F., Takenouchi, H., \& Yukiko, T. (2010). Entrepreneurial orientation and business performance of small and medium scale enterprises in Sri Lanka. Asian Social Science, 6(3), 34-46.

Flatten, T. C., Greve, G. I., \& Brettel, M. (2011). Absorptive capacity and firm performance in SMEs: The mediating influence of strategic alliances. European Management Review, 8, 137-152. http://dx.doi.org/10.1111/j.1740-4762.2011.01015.x 
Foley, P., \& Green, H. (1989). Small business success. London: Chapman.

Frishammar, J., \& Andersson, S. (2009). The overestimated role of strategic orientations for international performance of SMEs. Journal of Entrepreneurship, 7, 57-77. http://dx.doi.org/10.1007/s10843-008-0031-9

Frishammar, J., \& Horte, S. A. (2007). The role of market orientation and entrepreneurial orientation for new product development performance in manufacturing firms. Technology Analysis and Strategic Management, 19(6), 765-788. http://dx.doi.org/10.1080/09537320701711231

Fritz, W. (1996). Market orientation and corporate success: Findings from Germany. European Journal of Marketing, 30(8), 59-74. http://dx.doi.org/10.1108/03090569610130106

Gao, G. Y., Zhou, K. Z., \& Yim, C. K. (2007). On what should firm focus in transitional economies? A study of contingent value of strategic orientations in China. International Journal of Research in Marketing, 24(1), 3-15. http://dx.doi.org/10.1016/j.ijresmar.2006.09.004

Gatignon, H., \& Xuereb, J. M. (1997). Strategic orientation of the firm and new product performance. Journal of Marketing Research, 34(1), 77-90. http://dx.doi.org/10.2307/3152066

Grant, R. M. (1996). Toward a knowledge-based theory of the firm. Strategic Management Journal, 17(winter), 109-122. http://dx.doi.org/10.1002/smj.4250171110

Hakala, H. (2010). Configuring out strategic orientation. Finland: University of Vassa.

Harvey, G., Skelcher, C., Jas, P., \& Walshe, K. (2010). A knowledge-based approach to analyzing the performance of sector organizations. Public Management Review, 12(1), 77-97. http://dx.doi.org/10.1080/ 14719030902817923

Hayton, J., \& Zahra, S. (2005). Venture team human capital and absorptive capacity in high technology new ventures. International Journal of Technology Management, 31(3/4), 256-274. http://dx.doi.org/10.1504/ IJTM.2005.006634

Herath, H. M. A., \& Mahmood, R. (2013b). Mediatory effect of entrepreneurial self efficacy on the relationship between strategic orientation and SME performance: A research model. International Academic Research Journal of Business and Management, 1(8), 1-18.

Herath, H. M. A., \& Mahmood, R. B. (2013a). Strategic orientation based research model of SME performance for developing countries. Integrative Business and Economics, 2(1), 430-440.

Herath, H. M. A., \& Mahmood, R. (2012). Strategic orientations and SME performance; Moderating effect of absorptive capacity: A research model of firm performance. Proceedings of the 9th International Conference on Business Management Turning Crisis into Opportunities: Meeting the Unmet ICBM 2012 (pp. 21-41). Colombo: University of Sri Jayewardenepura.

Hoq, M. Z., \& Chauhan, A. A. (2011). Effects of organizational resources on organizational performance: An empirical study of SMEs. Interdisciplinary Journal of Contemporary Research in Business, 2(12), 373-385.

Hou, J. J. (2008). Toward a research model of market orientation and dynamic capabilities. Social Behaviour and Personality, 36(9), 1251-1268. http://dx.doi.org/10.2224/sbp.2008.36.9.1251

Huang, F., \& Rice, J. (2009). The role of absorptive capacity in facilitating "open innovation" outcomes: A study of Australian SMEs in the manufacturing sector. International Journal of Innovation Management, 13(2), 201-220. http://dx.doi.org/10.1142/S1363919609002261

Hult, G. T., Hurley, R. F., \& Knight, G. A. (2004). Innovativeness: Its antecedents and impact on business performance. Industrial Marketing Management, 33(5), 429-438. http://dx.doi.org/10.1016/j.indmarman. 2003.08.015

Hult, G. T., Ketchen, D. J., \& Slater, S. F. (2005). Market orientation and performance: An integration of disparate approaches. Strategic Management Journal, 26, 1173-1181. http://dx.doi.org/10.1002/smj.494

Inmyxai, S., \& Takahashi, Y. (2009). Entrepreneurs as decisive human resources and business performance for the Lao SMEs. Chinese Business Review, 8(7), 29-43.

Islam, M. A., Khan, M. A., \& Obaidullah, A. M. (2011). Effect of entrepreneur and firm characteristics on the business success of SMEs in Bangladesh. International Journal of Business Management, 6(3), 289-299.

Jeong, I., Pae, J. H., \& Zhou, D. (2006). Antecedents and consequences of the strategic orientations in new product development: The case of Chinese manufacturers. Industrial Marketing Management, 35(3), 348-358. http://dx.doi.org/10.1016/j.indmarman.2005.06.010 
Jolly, D. R., \& Therin, F. (2007). New venture technology sourcing: Exploring the effect of absorptive capacity, learning attitudes and past performance. Innovation, Management, Policy and Practice, 9(3-4), 235-248. http://dx.doi.org/10.5172/impp.2007.9.3-4.235

Kaplan, R. S., \& Norton, D. P. (1996). The balanced score card: Translating the strategy into action. Boston: Harvard Business School Press.

Keskim, H. (2006). Market orientation, learning orientation, and innovation capabilities in SMEs: An extended model. European Journal of Innovation Management, 9(4), 396-417. http://dx.doi.org/10.1108/ 14601060610707849

Kim, C., Zhan, W., \& Erramilli, M. K. (2011). Resources and performance of international joint ventures: The moderating role of absorptive capacity. Journal of Asia Business Studies, 5(2), 145-160. http://dx.doi.org/10.1108/15587891111152311

Klette, T. J., \& Johensen, F. (1998). Accumulation of R\&D capital and dynamic firm performance: A not-so-fixed effect model. ANNALES D'E'CONOMIE ET DE STATISTIQUE, 49, 389-419.

Kropp, F., Lindsay, N. J., \& Shoham, A. (2008). Entrepreneurial orientation and international entrepreneurial business venture start-up. International Journal of Entrepreneurial Behavior and Research, 14(2), 102-117. http://dx.doi.org/10.1108/13552550810863080

Kropp, F., Lindsay, N. J., \& Shoham, A. (2006). Entrepreneurial, market and learning orientations and international entrepreneurial business venture performance in South African firms. International Marketing Review, 23(5), 504-523. http://dx.doi.org/10.1108/02651330610703427

Lane, P. J., Salk, J. E., \& Lyles, M. A. (2001). Absorptive capacity, learning and performance in international joint ventures. Strategic Management Journal, 22, 1139-1161. http://dx.doi.org/10.1002/smj.206

Ledwith, A., \& Dwyer, O. (2009). Market orientation NPD performance, and organizational performance in small firms. Journal of Production and Innovation Management, 26, 652-661. http://dx.doi.org/10.1111/ j.1540-5885.2009.00690.x

Lee, T. S., \& Tsai, H. J. (2005). The effect of business operation mode on market orientation, learning orientation and innovativeness. Industrial Management Data Systems, 105(3), 325-348. http://dx.doi.org/10.1108/ 02635570510590147

Leitner, K. H., \& Idenberg, S. G. (2010). Generic strategies and firm performance in SMEs: A longitudinal study of Australian SMEs. Small Business Economics, 35(November), 169-189. http://dx.doi.org/10.1007/ s11187-009-9239-x

Li, J. J. (2005). The formation of Managerial networks of foreign firms in China: The effects of strategic orientations. Asia Pacific Journal of Management, 22(4), 423-443. http://dx.doi.org/10.1007/ s10490-005-4118-8

Liao, J., Welsch, H., \& Stoica, M. (2003). Organizational absorptive capacity and responsiveness: An empirical investigation of growth-oriented SMEs. Entrepreneurship Theory and Practice, 25(4), 63-85. http://dx.doi.org/10.1111/1540-8520.00032

Lichtenthaler, U. (2009). Absorptive capacity, environmental turbulence, and the complimentarily of organizational learning processes. Academy of Management Journal, 52, 822-846. http://dx.doi.org/10.5465/AMJ.2009.43670902

Lin, C. H., Peng, C. H., \& Kao, D. T. (2008). The innovativeness effect of market orientation and learning orientation on business performance. International Journal of Manpower, 29(8), 752-772. http://dx.doi.org/10.1108/01437720810919332

Lin-Van, Y., De-Van, Y., \& Yun-Horng, R. (2010). Learning and innovation in small and medium enterprises. Industrial Management Data and Systems, 110(2), 175-192. http://dx.doi.org/10.1108/02635571011020296

Liu, S. S., Luo, X., \& Shi, Y. Z. (2002). Integrating customer orientation, corporate entrepreneurship, and learning orientation in organizations-in-transition: An empirical study. International Journal of Research in Marketing, 19(4), 367-382. http://dx.doi.org/10.1016/S0167-8116(02)00098-8

Liu, S. S., Luo, X., \& Shi, Y. Z. (2003). Market oriented organizations in an emerging economy: A study of missing links. Journal of Business Research, 56(6), 481-491. http://dx.doi.org/10.1016/S0148-2963 (01)00265-X 
Lumpkin, G. T., \& Dess, G. G. (1996). Clarifying the entrepreneurial orientation construct and linking it to performance. Academy of Management Review, 21(1), 135-172.

Mancinelli, S., \& Mazzanti, M. (2009). Innovation, networking and complimentarily: Evidence on SME performance for a local economic system in North-Eastern Italy. Ann Reg Science, special issue, 567-597. http://dx.doi.org/10.1007/s00168-008-0255-6

March, J. G., \& Sutton, R. I. (1997). Organizational performance as a dependent variable. Organizational Science, 8(6), 698-706. http://dx.doi.org/10.1287/orsc.8.6.698

Mavondo, F. T., Chimhanzi, J., \& Stewart, J. (2005). Learning orientation and market orientation: Relationship with innovation, human resources practices and performance. European Journal of Marketing, 39(11/12), 1235-1263. http://dx.doi.org/10.1108/03090560510623244

Murray, T. S., \& Peyrefitte, J. (2007). Knowledge type and communication media choice in the knowledge transfer process. Journal of Managerial Issues, 19(spring), 111-133.

Muscio, A. (2007). The impact of absorptive capacity on SMEs collaboration. Economics of Innovation and New Technology, 16, 653-668. http://dx.doi.org/10.1080/10438590600983994

Narver, J., \& Slater, S. (1990). The effect of market orientation on business profitability. Journal of Marketing, 54(4), 20-35. http://dx.doi.org/10.2307/1251757

Newbert, S. L., Gopalakrishnan, S., \& Kirchoff, B. A. (2008). Looking beyond resources: Exploring the importance of entrepreneurship to firm level competitive advantage in technologically intensive industries. Technovation, 28, 6-19. http://dx.doi.org/10.1016/j.technovation.2007.07.002

$\mathrm{Ng}$, D. (2011). Thinking outside the box: An absorptive capacity: Approach to the product development process. International Food and Agribusiness Management Review, 14(3), 67-94.

Paladino, A. (2009). Financial champions and masters of innovation: Analyzing the effects of balancing strategic orientations. Journal of Product Innovation Management, 26, 616-626. http://dx.doi.org/10.1111/ j.1540-5885.2009.00687.x

Panday, V. M. (2012). Comparative analysis of development of SMEs in developed and developing countries. Proceedings of the 2012 International Conference on Business and Management (pp. 426-433). Phuket-Thailand: CAAL- International Education

Parida, V. (2009). Role of entrepreneurial orientation in overcoming the competency trap of absorptive capacity. Frontiers of Entrepreneurship Research.Retrieved from http://digitalknowledge.babson.edu/fe/vo129/iss4/9

Reijonena, H., \& komppulab, R. (2010). The adoption of market orientation in SMEs: Required capabilities and relation to success. Journal of Strategic Marketing, 18(1), 19-37. http://dx.doi.org/10.1080/ 09652540903511282

Rhee, J., Park, T., \& Lee, D. H. (2010). Drivers of innovativeness and performance for innovative SMEs in South Korea: Mediation of learning orientation. Technovation, 30, 65-75. http://dx.doi.org/10.1016/ j.technovation.2009.04.008

Rogers, E. W., \& Wright, P. M. (1998). Measuring Organizational performance in strategic human resource management: Looking beyond the lamp-post. Retrieved December 12, 2011, from http://www.ilr.cornel.edu /cahrs

Ruokonen, M., \& Saarenketo, S. (2009). The strategic orientations of rapidly internationalizing software companies. European Business Review, 21(1), 17-41. http://dx.doi.org/10.1108/09555340910925166

Salavou, H. (2005). Do customer and technology orientations influence product innovativeness in SMEs? Some new evidence from Greece. Journal of Marketing Management, 21(3/4), 307-338. http://dx.doi.org/10.1362/ 0267257053779082

Salavou, H., Baltas, G., \& Lioukas, S. (2004). Organizational innovation in SMEs: The importance of strategic orientation and competitive structure. European Journal of Marketing, 38(9/10), 1191-1112. http://dx.doi.org/10.1108/03090560410548889

Schindehutte, M., Morris, M. H., \& Kocak, A. (2008). Understanding market driving behavior: The role of entrepreneurship. Journal of Small Business Management, 46(1), 4-26. http://dx.doi.org/10.1111/ j.1540-627X.2007.00228.x

Schoot, R. V., Lugtig, P., \& Hox, J. (2012). A checklist of testing measurement invariance. European Journal of 
Developmental Psychology, 9(4), 486-492. http://dx.doi.org/10.1080/17405629.2012.686740

Shaw, V. (2000). Successful marketing strategies of German companies in UK. European Journal of Marketing, 34(1), 91-106. http://dx.doi.org/10.1108/03090560010306223

Sinkula, J. M., Baker, W. A., \& Noordewier, T. (1997). A framework for market based organizational learning: Linking values, knowledge, and behavior. Academy of Marketing Science Journal, 25(4), 305-318. http://dx.doi.org/10.1177/0092070397254003

Slater, S. F., \& Narver, J. C. (2000). The positive effect of market orientation on business profitability: A balanced replication. Journal of Business Research, 48(1), 69-73. http://dx.doi.org/10.1016/ S0148-2963(98)00077-0

Subhan, Q. A., Mehmood, M. R., \& Sattar, A. (2013). Innovation in small and medium enterprises and its impact on economic development in Pakistan. Proceedings of 6th international business and social sciences research conference (pp. 1-18). Dubai: World Academy of Social Sciences.

Sun, P. Y., \& Anderson, M. H. (2010). An examination of the relationship between absorptive capacity and organizational learning and a proposed integration. International Journal of Management Reviews, 12(2) 130-150. http://dx.doi.org/10.1111/j.1468-2370.2008.00256.x

Tajeddini, K. (2010). Effect of customer orientation and entrepreneurial orientation on innovativeness: Evidence from the hotel industry in Switzerland. Tourism Management, 31(2), 221-231. http://dx.doi.org/10.1016/ j.tourman.2009.02.013

Venkatraman, N. (1989). Strategic orientation of business enterprises: The construct dimensionality and measurement. Management Science, 35(8), 942-962. http://dx.doi.org/10.1287/mnsc.35.8.942

Venkatraman, N., \& Ramanujam, V. (1986). Measurement of business performance in strategy research: A comparison of approaches. The Academy of Management Review, 11(4), 801-814.

Wang, C. L. (2008). Entrepreneurial orientation, learning orientation and firm performance. Entrepreneurship Theory and Practice, 32(4), 635-657. http://dx.doi.org/10.1111/j.1540-6520.2008.00246.x

Wang, C., \& Han, Y. (2011). Linking properties of knowledge with innovation performance: The moderate role of absorptive capacity. Journal of Knowledge Management, 15(5), 802-819. http://dx.doi.org/10.1108/ 13673271111174339

Wymenga, P., Spanikova, V., Barker, A., Konings, J., \& Canton, E. (2012). European Union SMEs in 2012: Annual report on small and medium-sized enterprises in the European Union. Rotterdam: European Union.

Yangchao, G., Shunlin, Y., Lincheng, Y., \& Chialiao, S. (2011). A research on the relationship among market orientation, absorptive capability, organizational innovation climate and innovative behavior in Taiwan's manufacturing industry. African Journal of Business Management, 5(19), 7855-7863.

Yeoh, P. (2009). Realized and potential absorptive capacity: Understanding their antecedents and performance in the sourcing context. Journal of Marketing Theory and Practice, 17(1), 21-36. http://dx.doi.org/10.2753/ MTP1069-6679170102

Zahra, S., \& George, A. G. (2002). Absorptive capacity: A review, re-conceptualization, and extension. Academic Management Review, 27(2), 185-203.

Zehir, C., \& Eren, M. S. (2007). Field research on impacts of some organizations on corporate entrepreneurship and business performance in the Turkish automotive industry. Journal of American Academy of Business Cambridge, 10(2), 170-176.

Zhang, D. D. (2009). Absorptive capacity and its mediating effect on the learning and market orientations' influence on performance. International Journal of Technology Marketing, 4(2/3), 275-288. http://dx.doi.org/10.1504/IJTMKT.2009.026874

Zhou, K. Z., \& Li, C. B. (2010). How strategic orientations influence the building of dynamic capability in emerging economies. Journal of Business Research, 63, 224-231. http://dx.doi.org/10.1016/ j.jbusres.2009.03.003

Zonooz, B. H., Farzam, V., Satarifar, M., \& Bakhshi, L. (2011). The relationship between knowledge transfer and competitiveness in SMEs with emphasis on absorptive capacity and combinative capabilities. International Business and Management, 2(1), 59-85. 


\section{Copyrights}

Copyright for this article is retained by the author(s), with first publication rights granted to the journal.

This is an open-access article distributed under the terms and conditions of the Creative Commons Attribution license (http://creativecommons.org/licenses/by/3.0/). 